Relations industrielles

Industrial Relations

\title{
Le chômage
}

Volume 16, numéro 2, avril 1961

URI : https://id.erudit.org/iderudit/1021809ar

DOI : https://doi.org/10.7202/1021809ar

Aller au sommaire du numéro

\section{Éditeur(s)}

Département des relations industrielles de l’Université Laval

\section{ISSN}

0034-379X (imprimé)

1703-8138 (numérique)

Découvrir la revue

Citer ce document

(1961). Le chômage. Relations industrielles / Industrial Relations, 16(2), 259-262. https://doi.org/10.7202/1021809ar

Tous droits réservés @ Département des relations industrielles de l’Université Laval, 1961
Ce document est protégé par la loi sur le droit d'auteur. L’utilisation des services d'Érudit (y compris la reproduction) est assujettie à sa politique d'utilisation que vous pouvez consulter en ligne.

https://apropos.erudit.org/fr/usagers/politique-dutilisation/ 


\section{INFORMATIONS}

\section{LE CHÔMAGE}

\section{Extraits du Mémoire de la Confédération des Syndicats Nationaux présenté au Cabinet fédéral le 2 février 1961}

La CSN continue de croire au caractère primordial des valeurs spirituelles mais elle ne veut pas que cette croyance, étant donné le cadre juridique dans lequel se déploie l'activité syndicale au Canada, violente la conscience de ses adhérents actuels et éventuels.

L'homme ne vit pas de pain seulement et, si nous ne sommes pas en mesure de créer une société dans laquelle il pourra satisfaire tous ses besoins d'homme, nous aurons failli à notre tâche commune...

... Nous sommes convaincus qu'une vigoureuse et généreuse politique d'investissement dans le secteur public, une baisse des impôts en faveur des petits salariés, une augmentation des bénéfices sociaux et une revision de notre politique fiscale et monétaire pourraient constituer autant de stimulants qui agiraient favorablement sur notre économie. Evidemment, l'ensemble de ces mesures peut signifier, pour une certaine période, l'adoption de budgets déficitaires mais, selon nous, il vaut mieux envisager les mauvais effets d'une telle politique que d'abandonner à leur sort des centaines de milliers de citoyens canadiens condamnés à l'inaction et à la misère. L'attitude la plus repréhensible, dans les circonstances actuelles, est celle d'attendre que les choses s'arrangent d'elles mêmes...

... L'an dernier notre mémoire, à votre Gouvernement, contenait le projet de création d'un conseil d'orientation économique. Ce mémoire fut l'objet de commentaires très élogieux de la part du Premier Ministre. Lors de la conférence sur le chômage, nous avons répété notre suggestion et le Premier Ministre, dans une déclaration publique, l'a qualifiée de « socialiste ».

Nous tenons à réaffirmer que la formation, au niveau national, d'un conseil d'orientation économique s'impose et que cette proposition ne mérite pas l'anathème qu'on a prononcé contre elle. Des conseils semblables existent dans plusieurs pays dont l'économie est dominée par l'entreprise privée. Au Canada même, ce n'est pas une formule nouvelle. Entre un étatisme rigide et un laissez-faire absolu, il y a place pour une organisation économique rationnelle ordonnée au bien commun de la nation. Le Conseil d'orientation économique pourrait jouer un rôle important dans ce domaine.

Nous n'avons pas d'objection au conseil sur la productivité que veut créer le Gouvernement mais, à notre avis, ce conseil aurait dû constituer une sorte de sous-comité du conseil d'orientation économique. La CNS acceptera volontiers, si elle y est invitée, à être représentée au conseil sur la productivité mais elle est 
convaincue qu'il s'agit là d'un instrument dont l'efficacité, au point de départ, est très limitée et qui ne peut produire des effets qu'à très long terme.

Toutes les mesures particulières qui peuvent être proposées pour stabiliser notre économie et assurer le plein emploi n'atteindront jamais intégralement leur but si elles ne s'intègrent pas dans un plan d'ensemble dont l'Etat aura la surveillance. Nous suggérons donc l'adoption d'une législation sur le plein emploi qui permettra au Gouvernement fédéral de s'assurer la collaboration des provinces et des municipalités en vue de combattre le chômage et d'utiliser, au maximum, nos ressources humaines et matérielles.

... La loi d'assurance-chômage n'est pas un substitut pour une politique de plein emploi ni un instrument approprié pour combattre les effets des crises économiques.

... La CSN est d'avis que tant et aussi longtemps que le Canada ne s'acheminera pas d'une façon résolue dans la voie de la planification économique, les Canadiens seront dans l'insécurité chronique.

... Afin que la population canadienne se fasse une idée précise des ravages causés par le chômage, nous croyons que les statistiques publiées par le gouvernement fédéral devraient être beaucoup plus complètes qu'elles ne le sont. On devrait indiquer le nombre de chômeurs enregistrés de même que le nombre de bénéfciaires de la Loi de l'assurance-chômage, ainsi que le nombre de personnes qui ne retirent pas de prestations d'assurance-chômage et qui cherchent un emploi. Enfin, on devrait mentionner le nombre d'heures de travail perdues à cause du chômage et les sommes d'argent que les travailleurs n'ont pas touchées par suite du chômage. Ces chiffres démontreront que les salaires et les heures de travail perdus à cause des grèves sont insignifiants à côté du coût du chômage.

... A ce sujet, la CSN, tout en favorisant en principe la propriété privée des biens de production, considère que le gouvernement devrait, en ce qui concerne l'exploitation des ressources naturelles, participer davantage à l'aménagement d'entreprises en collaboration avec les capitaux canadiens, plutôt que de favoriser l'affluence de capitaux étrangers en provenance, pour la plus grande partie d'un même pays, ce qui peut constituer un danger grave pour l'indépendance économique du Canada. En cette matière, nous croyons que l'expérience des pays scandinaves est fort intéressante et qu'il y aurait lieu pour le Canada de s'en inspirer.

... La CSN demande au Gouvernement fédéral et au Gouvernement provincial, par voies de législation appropriée, des tribunaux d'arbitrage des prix qui auraient une double fonction:

a) juger des motifs invoqués par les producteurs primaires ou par l'industrie de base du pays ou encore par les distributeurs des produits et services essentiels à la nation, à l'appui des hausses de prix sollicitées et de les faire connaître au public s'ils ne sont pas justifiés;

b) enquêter dans tout secteur de la vie économique afin de dépister les abus dans le domaine de la structure financière des entreprises en autant que cette structure peut influencer les prix... 


\section{Quotations from the Submission of The Canadian Labour Congress to the Senate Special Committee on Manpower and Employment, Ottawa, January 26, 1961.}

The problem of unemployment is not a single problem but a bundle of many problems. There is, accordingly, not one answer but a bundle of answers. (p. 2)

... So our present unemployment problem is not mainly, or even substantially, a matter of recession, of a down-turn in production. If we could get production back to where it was in January 1960, before the down-turn began, about fourfiths of our present unemployment problem would still be with us. (p. 4)

... Over the whole twelve-year period (1947-1959), there had been virtually no net change in employment in the goods-producing industries (the slight aparent fall is the result of the slightly different basis of the industry figures of jobs in the two years), despite the fact that the actual quantity of goods produced must have just about doubled. (p. 16)

... There are still many who seriously under-rate the economic value of public investment. They tend to regard social capital at best as a necessary evil, and always as an overhead cost which the private sector of the economy must support. Consequently, they quickly conclude that the less spent on the public sector the better.

This is a completely false concept, because it ignores the extremely important economic inter-relationship between public and private capital. From a strictly economic point of view, i.e., apart altogether from social values, public capital may be just as productive in creating wealth as private capital. For example, the trucking industry would not survive long without a network of highways; the shipping industry is highly dependent on canals and locks provided by the public sector; commercial planes are the beneficiaries of huge sums of public investment in air terminals and all the other costly paraphernalia necessary for regulating modern airways; private industry is dependent on schools and universities for the general education and the technical, scientific and professional training of its people, and it has borrowed a mass of technology developed by governments in the prosecution of wars. (pp. 23-24)

... Education, which is largely financed by public expenditures, is being increasingly recognized as a very important source of economic growth. Economists have been inclined to talk almost solely in terms of investment in machinery, in plant, in physical resources, virtually ignoring the equally, if perhaps not more important, need for investing in the educational, scientific and technological training, and general welfare of human beings. (p. 25)

... Some of the critics could no doubt understand, even applaud, the idea of shortening hours, by itself; that is, shortening hours and shortening weekly pay proportionately. That could be spreading the work, an admirable manifestation of willingness by employed workers to shore what work there is with their unfortunate unemployed brethren. The Congress' reply would be that it might be noble but it would not be sound economics. Sharing the work in this fashion is just sharing the poverty, spreading the unemployment thin. It does nothing whatever 
to get rid of the poverty, get rid of the unemployment is the aim of any full employment policy, and to that aim a mere shortening of hours, without maintenance of take-home pay, would contribute nothing whatever. (p. 91)

\section{RÉFLEXIONS CHRÉTIENNES EN FACE DE L'ÉVOLUTION}

\section{Cardinal Richaud, archevêque de Bordeaux}

Le cadre de la vie économique et sociale se transforme à une vitesse accélérée.

La croissance des grandes unités industrielles, la nationalisation d'importants secteurs de la production, la transformation des exploitations rurales, l'établissement des grands ensembles, l'extrême facilité des communications et la célérité accrue des informations, la création de grands espaces économiques différents des territoires régionaux ou nationaux, les formes nouvelles de la concurrence technique ou économique, les transferts d'activité et de revenus que suppose l'aide aux pays sous-développés, posent autant de problèmes que le chrétien doit éclairer la lumière de sa foi et des principes souvent rappelés par les Chefs de l'Eglise.

Tous, il faut le reconnaître, se trouvent engagés dans ce mouvement qui, en bien des points, paraît irréversible: dirigeants de la politique ou des affaires, possédants, responsables syndicaux, cadres et techniciens, employés et ouvriers, agriculteurs, commerçants, financiers, enseignants, magistrats, médecins, personnel de la santé et tous membres des professions libérales ou des services administratifs.

Ainsi l'évolution actuelle sera volontiers envisagée par les chrétiens, s'ils veulent étudier le phénomène d'une façon objective et correspondre à leur vocation fraternelle, en dehors et au-dessus de toute préoccupation de classe, de milieu, de profession, de race. Pour eux, la progression de l'humanité ne peut être que communautaire, sans cloisonnement ni exclusive, si cependant tous ne peuvent y participer de la même façon. Certes, on ne saurait oublier les problèmes particuliers à telle ou telle catégorie humaine, à telle ou telle nation. Mais la conjoncture actuelle renforce le souci que chaque groupe doit conserver de se préoccuper du bien commun. Il y aura lieu souvent de dépasser ses préoccupations particulières, si l'on veut sincèrement résoudre les problèmes gigantesques qui se dressent aujourd'hui devant l'humanité.

Il ne suffit donc pas à l'économiste et au sociologue chrétiens d'analyser avec précision les situations et les institutions présentes. Toujours en marche pour la réalisation de sa destinée éternelle, le croyant doit, plus que tout autre, être porté à regarder loin pour voir clair. Il ne peut se contenter d'attendre, de rêver, de critiquer. Il a le devoir de préparer l'avenir par des études, des projets, des plans; il confrontera ses propres visées avec les recherches et les initiatives que d'autres entreprennent. Devant l'ampleur des tâches, la coopération de tous les responsables, à quelque degré de l'échelle sociale qu'ils appartiennent, est une nécessité. L'avenir de l'humanité est entre les mains de toutes les classes et de toutes les races qui la composent. 